\title{
Microwave-Assisted Regioselective Synthesis and 2D-NMR Studies of New 1,2,3-Triazole Compounds Derived from Acridone
}

\author{
Mohammed Aarjane $\left(\mathbb{D},{ }^{1}\right.$ Siham Slassi, ${ }^{1}$ Bouchra Tazi, ${ }^{2}$ and Amina Amine ${ }^{1}$ \\ ${ }^{1}$ Laboratory of Chemistry/Biology Applied to the Environment, Faculty of Science, University Moulay Ismail, BP 11201 Zitoune, \\ Meknes, Morocco \\ ${ }^{2}$ National School of Agriculture, Department of Basic Sciences, Meknes, Morocco \\ Correspondence should be addressed to Mohammed Aarjane; aarjane.mohammed@gmail.com
}

Received 9 February 2021; Revised 15 March 2021; Accepted 20 March 2021; Published 10 April 2021

Academic Editor: Grigoris Zoidis

Copyright (C) 2021 Mohammed Aarjane et al. This is an open access article distributed under the Creative Commons Attribution License, which permits unrestricted use, distribution, and reproduction in any medium, provided the original work is properly cited.

\begin{abstract}
A simple and mild protocol towards the synthesis of new 1,2,3-triazole compounds derived from acridone has been developed via regiospecific 1,3-dipolar cycloaddition reaction between 10-(prop-2-yn-1-yl)acridone derivatives and aromatic azides using CuI as a catalyst. The cycloaddition reaction has been performed using conventional as well as microwave-assisted methods. Microwave-assisted synthesis caused a significant reduction in the reaction times and improvement in the yields of all the synthesized compounds compared with the conventional method. The structure of the 1,4-disubstituted 1,2,3-triazoles has been elucidated by IR, HRMS, ${ }^{1} \mathrm{H}-\mathrm{NMR},{ }^{13} \mathrm{C}-\mathrm{NMR}$, and 2D NMR $\left({ }^{1} \mathrm{H}_{-}{ }^{13} \mathrm{C} \mathrm{HMBC},{ }^{1} \mathrm{H}-{ }^{1} \mathrm{H}\right.$ COSY, and ${ }^{1} \mathrm{H}-{ }^{1} \mathrm{H}$ NOESY) spectroscopies.
\end{abstract}

\section{Introduction}

Triazoles derivatives constitute an interesting class of heterocyclic compounds with a wide spectrum of biological activities such as antibacterial [1,2], antifungal [3], anti-inflammatory [4,5], tyrosine inhibitors [6], and anticancer $[7,8]$. Furthermore, the preparation of 1,2,3-triazole was extensively studied [9-11]. The key for the preparation of these compounds is the 1,3-dipolar cycloaddition reaction between alkynes and azides, first described by Huisgen et al. [12]. This method requires long reaction time and high temperature, and it leads to the formation of two regioisomers 1,4-disubstituted and 1,5-disubstituted triazoles [13]. After, it was reported that the copper(I)-catalyzed azide-alkyne cycloaddition (CuAAC) makes the reaction of cycloaddition quantitative and selective for the synthesis of 1,4-disubstituted 1,2,3-triazole [14]. This synthetic method is an interesting topic in organic synthesis, since it constitutes a powerful bond forming reaction with many applications including different fields from drug discovery to materials science $[15,16]$. On the other hand, the acridone nucleus constitutes an interesting class of natural products that serve as chemical intermediates in the synthesis of several alkaloids [17]. Acridones were known for their pharmacological activities as antiviral $[18,19]$, antimicrobial [20-22], antitumor [23, 24], antimalarial $[25,26]$, and anticancer $[27,28]$. Moreover, the fluorescence of acridones allows these molecules to be important chemosensors for selective recognition of metals and pollutants in biological and ecological areas [29].

The microwave-assisted synthesis method has become an interesting tool to preserve the environment by reducing the reaction time, efficient internal heat transfer, as well as increasing the yield of reaction [20]. Numerous reactions have proven to result in selectivity or higher yield under microwave irradiation compared with the conventional method [30-32]. Among these reactions, the copper(I) catalyzed azide-alkyne cycloaddition (CuAAC) [33].

Based on subsequent studies, the 1,2,3-triazole derivatives from acridone are showing an interesting antibacterial activity against pathogenic strains [34]. On the other hand, the flatness of the polycyclic aromatic nucleus in these structures generally allows them easy intercalation between the adjacent base pairs of the double helix of DNA. This interesting property is the cornerstone of some biological activities of these molecules $[35,36]$. In this view, we have synthesized new 1,2,3-triazole compounds derived from 
acridone via the 1,3-dipolar cycloaddition reaction using an environment friendly method. The synthesized compound was characterized using different spectroscopic methods such as IR, ${ }^{1} \mathrm{H} \mathrm{NMR},{ }^{13} \mathrm{C} \mathrm{NMR}$, and HR-MS. Also, the regioselectivity of the cycloaddition reaction under microwave irradiation was confirmed by $2 \mathrm{D}$ NMR including ${ }^{1} \mathrm{H}$ ${ }^{13} \mathrm{C}$ HMBC, ${ }^{1} \mathrm{H}_{-}{ }^{1} \mathrm{H}$ COSY, and ${ }^{1} \mathrm{H}_{-}{ }^{1} \mathrm{H}$ NOESY.

\section{Materials and Methods}

2.1. General Details. All materials were purchased from commercial suppliers. The ${ }^{1} \mathrm{H},{ }^{13} \mathrm{C}$, and DEPT- $135^{\circ} \mathrm{NMR}$ spectra were recorded with Bruker Avance $300 \mathrm{MHz}$. Mass spectrometric measurements were recorded using the Exactive $^{\mathrm{TM}}$ Plus Orbitrap Mass Spectrometer. IR spectra were recorded using the JASCO FT-IR 4100 spectrophotometer. Microwave irradiation was carried out with CEM Discover $^{\mathrm{TM}}$.

\subsection{Synthesis}

2.2.1. 10-(Prop-2-yn-1-yl)acridone (1). To a mixture of acridone $(0.5 \mathrm{~g}, 2.5 \mathrm{mmol})$, potassium carbonate $(0.55 \mathrm{~g}$, $3 \mathrm{mmol})$, and $\operatorname{TBAB}(0.5 \mathrm{~g}, 2.5 \mathrm{mmol})$ in $\operatorname{DMF}(7 \mathrm{ml})$, propargyl bromide $(0.4 \mathrm{~g}, 3.6 \mathrm{mmol})$ was added, and the mixture was then irradiated for $10 \mathrm{~min}$. Microwave irradiation power was set at $200 \mathrm{~W}$ maximum. After that, it was poured into water, and the white yellow formed precipitate was recrystallized from methanol-DMF.

White yellow solid; yield: $75 \%, \mathrm{mp}=206-208^{\circ} \mathrm{C}$. IR (KBr): 3208, 3010, 2210, 1638, and $1598 \mathrm{~cm}^{-1} .-{ }^{1} \mathrm{H}$ NMR $\left(300 \mathrm{MHz}, \mathrm{DMSO}-\mathrm{d}_{6}, 25^{\circ} \mathrm{C}, \mathrm{TMS}\right): \delta=8.34(\mathrm{~d}, J=7.8 \mathrm{~Hz}$, $1 \mathrm{H}, \mathrm{Ar}-\mathrm{H}), 8.12$ (s, $1 \mathrm{H}, \mathrm{Ar}-\mathrm{H}), 7.87-7.86$ (m, 4H, Ar-H), 7.37-7.38 (m, 2H, Ar-H), 5.32 (s, 2H, CH2), 2.41 (s, 1H, $\mathrm{CH}), 2.38$ (s, 3H, CH3). ${ }^{13} \mathrm{C} \mathrm{NMR}\left(75 \mathrm{MHz}, \mathrm{DMSO}-\mathrm{d}_{6}, 25^{\circ} \mathrm{C}\right.$, TMS) $\delta 177.18,141.78,134.76,134.47,127.78,127.07$, $123.37,122.20,118.44,116.35,79.12,76.16,36.12$, and 20.18 .

\subsection{General Procedure for the Synthesis of Acridone-Triazole Derivatives $(2 a-h)$}

2.3.1. Conventional Method. A mixture of 10-(prop-2-yn-1-yl) acridone $(0.23 \mathrm{~g}, 1 \mathrm{mmol})$, CuI $(0.02 \mathrm{~g}, 1 \mathrm{mmol})$, and TEA $(0.14 \mathrm{~g}, 1.2 \mathrm{mmol})$ was suspended in $10 \mathrm{~mL} \mathrm{DMF}$. To this mixture, aromatic azide $(2 \mathrm{mmol})$ was added at room temperature, and the reaction mixture was stirred at $80^{\circ} \mathrm{C}$ for $4-8 \mathrm{~h}$. After completion of the reaction, water $(25 \mathrm{ml})$ was added, and the mixture was extracted with chloroform; the organic layer was evaporated in high vacuum, and the obtained product was purified by recrystallization in DMF.

2.3.2. Microwave-Assisted Method. A mixture of 10-(prop-2yn-1-yl)acridone (0.23 g, $1 \mathrm{mmol}), \mathrm{CuI}(0.01 \mathrm{~g}, 0.5 \mathrm{mmol})$, and TEA $(0.07 \mathrm{~g}, 0.6 \mathrm{mmol})$ was suspended in $10 \mathrm{~mL}$ of solvent in a glass vial equipped with a small magnetic stirring bar. To this, aromatic azide $(2 \mathrm{mmol})$ was added, and the vial was tightly sealed. The mixture was then irradiated for $10 \mathrm{~min}$. Microwave irradiation power was set at $200 \mathrm{~W}$ maximum. After completion of the reaction, water $(25 \mathrm{ml})$ was added, and the mixture was extracted with chloroform; the organic layer was evaporated in high vacuum, and the obtained product was purified by recrystallization in DMF.

2.3.3. 10-((1-(o-Tolyl)-1H-1,2,3-triazol-4-yl)methyl)acridine-9(10 H)-one (2a). Yellow solid; yield: $90 \%, \mathrm{mp}=224-226^{\circ} \mathrm{C}$. IR (KBr): $3112,3063,1638,1600$, and $1502 \mathrm{~cm}^{-1}$. ${ }^{1} \mathrm{H}$ NMR $\left(300 \mathrm{MHz}, \mathrm{DMSO}_{-} \mathrm{d}_{6}, 25^{\circ} \mathrm{C}, \mathrm{TMS}\right) \delta 8.62$ (s, $1 \mathrm{H}, \mathrm{CH}-$ triazole), 8.40 (dd, J=8.0, $1.7 \mathrm{~Hz}, 2 \mathrm{H}, \mathrm{Ar}-\mathrm{H}), 8.05$ (d, $J=8.8 \mathrm{~Hz}, 2 \mathrm{H}, \mathrm{Ar}-\mathrm{H}), 7.86$ (ddd, $J=8.7,6.9,1.8 \mathrm{~Hz}, 2 \mathrm{H}$, $\mathrm{Ar}-\mathrm{H}), 7.57-7.34$ (m, 6H, Ar-H), 5.91 (s, 2H, CH2), and 2.11 (s, $3 \mathrm{H}, \mathrm{CH} 3) .{ }^{13} \mathrm{C}$ NMR $\left(75 \mathrm{MHz}, \mathrm{DMSO}_{-} \mathrm{d}_{6}, 25^{\circ} \mathrm{C}\right.$, TMS) $\delta$ 176.68, 142.58, 141.91, 136.06, 134.14, 132.95, 131.29, 129.79, 126.90, 126.59, 125.91, 125.19, 121.76, 121.49, 116.39, 41.56, and 17.31. MS (ESI) for $\mathrm{C}_{23} \mathrm{H}_{18} \mathrm{~N}_{4} \mathrm{O}[\mathrm{M}+\mathrm{H}]^{+}$, calcd: 367.1511, found: 367.1511 .

2.3.4. 4-(4-((9-Oxoacridin-10(9H)-yl)methyl)-1H-1,2,3-triaz ol-1-yl)benzoic Acid (2b). Yellow solid; yield: 79\%, $\mathrm{mp}>300^{\circ} \mathrm{C}$. IR (KBr): 3397, 3112, 3063, 1702, 1638, 1600, and $1502 \mathrm{~cm}^{-1}$. ${ }^{1} \mathrm{H}$ NMR $\left(300 \mathrm{MHz}, \mathrm{DMSO}-\mathrm{d}_{6}, 25^{\circ} \mathrm{C}\right.$, TMS) $\delta 8.95$ (s, $1 \mathrm{H}, \mathrm{CH}$-triazole), $8.41(\mathrm{dd}, J=8.0,1.7 \mathrm{~Hz}, 2 \mathrm{H}$, $\mathrm{Ar}-\mathrm{H}), 8.08-7.95$ (m, 6H, Ar-H), 7.87-7.81 (m, 2H, Ar-H), 7.41-7.36 (m, 2H, Ar-H), and 5.92 (s, 2H, CH2). ${ }^{13} \mathrm{C} \mathrm{NMR}$ $\left(75 \mathrm{MHz}, \mathrm{DMSO}-\mathrm{d}_{6}, 25^{\circ} \mathrm{C}\right.$, TMS) $\delta 176.73,164.54,144.17$, $141.89,139.29,137.23,134.24,132.29,131.06,128.08,126.63$, $121.80,121.68,121.53,119.88,117.18,116.24$, and 41.80 . HRMS (ESI) for $\mathrm{C}_{23} \mathrm{H}_{16} \mathrm{~N}_{4} \mathrm{O}_{3}[\mathrm{M}+\mathrm{H}]^{+}$, calcd: 397.1255, found: 397.1255 .

2.3.5. 10-((1-(m-Tolyl)-1H-1,2,3-triazol-4-yl)methyl)acridine-9(10H)-one (2c). Yellow solid; yield: $85 \%, \mathrm{mp}>300^{\circ} \mathrm{C}$. IR (KBr): 3120, 3063, 1637, 1606, 1597, and $1507 \mathrm{~cm}^{-1} \cdot{ }^{1} \mathrm{H}$ NMR $\left(300 \mathrm{MHz}, \mathrm{DMSO}-\mathrm{d}_{6}, 25^{\circ} \mathrm{C}\right.$, TMS) $\delta 8.73(\mathrm{~s}, 1 \mathrm{H}, \mathrm{CH}-$ triazole), 8.40 (dd, $J=8.0,1.7 \mathrm{~Hz}, 2 \mathrm{H}, \mathrm{Ar}-\mathrm{H}), 7.99$ (d, $J=8.1 \mathrm{~Hz}, 2 \mathrm{H}, \mathrm{Ar}-\mathrm{H}), 7.83(\mathrm{t}, 2 \mathrm{H}, \mathrm{Ar}-\mathrm{H}), 7.70$ (d, J=7.2 Hz, $2 \mathrm{H}, \mathrm{Ar}-\mathrm{H}), 7.36$ (d, J=7.2 Hz, 4H, Ar-H), 5.86 (s, 2H, CH2), and $2.36(\mathrm{~s}, 3 \mathrm{H}, \mathrm{CH} 3) .{ }^{13} \mathrm{C} \mathrm{NMR}\left(75 \mathrm{MHz}, \mathrm{DMSO}-\mathrm{d}_{6}, 25^{\circ} \mathrm{C}\right.$, TMS) $\delta 177.14,144.10,142.51,138.86,134.62,130.58,127.15$, $122.42,121.94,120.53,116.65,42.39$, and 20.96. MS (ESI) for $\mathrm{C}_{23} \mathrm{H}_{16} \mathrm{~N}_{4} \mathrm{O}_{3}[\mathrm{M}+\mathrm{H}]^{+}$, calcd: 367.1401, found: 367.1404.

2.3.6. 2-(4-((9-Oxoacridin-10(9H)-yl)methyl)-1H-1,2,3-triaz ol-1-yl)benzoic Acid (2d). Yellow solid; yield: 75\%, $\mathrm{mp}>300^{\circ} \mathrm{C}$. IR (KBr): 3405, 3109, 3053, 1700, 1639, 1602, and $1500 \mathrm{~cm}^{-1}$. ${ }^{1} \mathrm{H}$ NMR $\left(300 \mathrm{MHz}, \mathrm{DMSO}-\mathrm{d}_{6}, 25^{\circ} \mathrm{C}\right.$, TMS) $\delta 8.93(\mathrm{~s}, 1 \mathrm{H}, \mathrm{CH}$-triazole), 8.37 (dd, $J=8.0,1.7 \mathrm{~Hz}, 2 \mathrm{H}$, Ar-H), 8.04-7.98 (m, 3H, Ar-H), 7.69-7.62 (M, 5H, Ar-H), 7.34-7.26 (m, 2H, Ar-H), and 5.84 (s, 2H, CH2). ${ }^{13} \mathrm{C}$ NMR (75 MHz, DMSO- $\mathrm{d}_{6}, 25^{\circ} \mathrm{C}$, TMS) $\delta 176.85,161.51,144.90$, $142.50,140.10,135.54,132.97,128.69,125.56,124.11,121.80$, $121.53,119.87,117.76,116.24$, and 41.80. MS (ESI) for $\mathrm{C}_{23} \mathrm{H}_{16} \mathrm{~N}_{4} \mathrm{O}_{3}[\mathrm{M}+\mathrm{H}]^{+}$, calcd: 397.1507, found: 397.1507. 
2.3.7. 2-Methyl-10-((1-(o-tolyl)-1H-1,2,3-triazol-4-yl)methyl) acridine-9(10H)-one (2e). Yellow solid; yield: $89 \%$, $\mathrm{mp}>300^{\circ} \mathrm{C}$. IR (KBr): 3110, 3065, 1637, 1610, 1601, and $1502 \mathrm{~cm}^{-1} .{ }^{1} \mathrm{H}$ NMR $\left(300 \mathrm{MHz}\right.$, DMSO-d ${ }_{6}, 25^{\circ} \mathrm{C}$, TMS) $\delta 8.59$ (s, $1 \mathrm{H}, \mathrm{CH}$-triazole), 8.38 (d, J=7.9 Hz, $1 \mathrm{H}, \mathrm{Ar}-\mathrm{H}), 8.25-8.12$ (m, $1 \mathrm{H}, \mathrm{Ar}-\mathrm{H}), 8.01$ (dd, $J=19.3,8.7 \mathrm{~Hz}, 2 \mathrm{H}, \mathrm{Ar}-\mathrm{H}), 7.83(\mathrm{t}$, $J=7.9 \mathrm{~Hz}, 1 \mathrm{H}, \mathrm{Ar}-\mathrm{H}), 7.68(\mathrm{~d}, J=8.7 \mathrm{~Hz}, 1 \mathrm{H}, \mathrm{Ar}-\mathrm{H}), 7.58-7.25$ (m, 5H, Ar-H), 5.89 (s, 2H, CH2), 2.46 (s, 3H, CH3), and 2.10 (s, 3H, CH3). ${ }^{13} \mathrm{C}$ NMR $\left(75 \mathrm{MHz}\right.$, DMSO-d 6 , $25^{\circ} \mathrm{C}$, TMS) $\delta$ $176.50,141.75,140.03,136.06,135.43,133.94,132.94,131.28$, $130.68,129.79,126.89,126.61,125.90,125.82,125.13,121.64$, $121.21,116.40,116.24,41.44,20.18$, and 17.31. MS (ESI) for $\mathrm{C}_{24} \mathrm{H}_{20} \mathrm{~N}_{4} \mathrm{O}[\mathrm{M}+\mathrm{H}]^{+}$, calcd: 381.1669 , found: 381.1669 .

2.3.8. 2-Methyl-4-(4-((9-oxoacridin-10(9H)-yl)methyl)-1H-1,2,3triazol-1-yl)benzoic Acid (2f). Yellow solid; yield: 82\%, $\mathrm{mp}>300^{\circ} \mathrm{C}$. IR (KBr): $3398,3110,3063,1700,1638,1609$, and $1502 \mathrm{~cm}^{-1} .{ }^{1} \mathrm{H}$ NMR (300 MHz, DMSO-d 6 , $25^{\circ} \mathrm{C}$, TMS) $\delta 8.93$ (s, $1 \mathrm{H}, \mathrm{CH}$-triazole), 8.40 (s, 1H, Ar-H), $8.14(\mathrm{~s}, 1 \mathrm{H}, \mathrm{Ar}-\mathrm{H})$, 8.04-7.95 (m, 5H, Ar-H), 7.87-7.82 (m, 2H, Ar-H), $7.37(\mathrm{t}$, $J=7.4 \mathrm{~Hz}, 2 \mathrm{H}, \mathrm{Ar}-\mathrm{H}), 5.90$ (s, 2H, CH2), and 2.29 (s, 3H, CH3). ${ }^{13} \mathrm{C}$ NMR $\left(75 \mathrm{MHz}\right.$, DMSO-d ${ }_{6}, 25^{\circ} \mathrm{C}$, TMS) $\delta 176.55,164.99$, $144.24,141.72,139.98,139.27,135.52,134.03,130.72,126.64$, $125.86,121.68,121.24,116.25,116.07,41.65$, and 20.18. MS (ESI) for $\mathrm{C}_{24} \mathrm{H}_{18} \mathrm{~N}_{4} \mathrm{O}_{3}[\mathrm{M}+\mathrm{H}]^{+}$, calcd: 411.1403, found: 411.1408 .

\subsubsection{2-Methyl-10-((1-(m-tolyl)-1H-1,2,3-triazol-4-yl)} methyl)acridin-9(10H)-one (2g). Yellow solid; yield: $81 \%$, $\mathrm{mp}>300^{\circ} \mathrm{C}$. IR (KBr): 3112, 3063, 1638, 1600, and $1502 \mathrm{~cm}^{-1}$. ${ }^{1} \mathrm{H}$ NMR $\left(300 \mathrm{MHz}, \mathrm{DMSO}-\mathrm{d}_{6}, 25^{\circ} \mathrm{C}\right.$, TMS) $\delta$ $8.70(\mathrm{~s}, 1 \mathrm{H}$, triazole), 8.33 (d, $J=7.2 \mathrm{~Hz}, 1 \mathrm{H}, \mathrm{Ar}-\mathrm{H}), 8.14$ (s, $1 \mathrm{H}, \mathrm{Ar}-\mathrm{H}), 7.94-7.53\left(\mathrm{~m}, 6 \mathrm{H}, \mathrm{Ar}-\mathrm{H}^{\prime}\right), 7.33(\mathrm{~d}, J=7.2 \mathrm{~Hz}$, $3 \mathrm{H}, \mathrm{Ar}-\mathrm{H}), 5.78(\mathrm{~s}, 2 \mathrm{H}, \mathrm{CH} 2), 2.42(\mathrm{~s}, 3 \mathrm{H}, \mathrm{CH} 3)$, and $2.32(\mathrm{~s}$, $3 \mathrm{H}, \mathrm{CH} 3) .{ }^{13} \mathrm{C}$ NMR $\left(75 \mathrm{MHz}, \mathrm{DMSO}-\mathrm{d}_{6}, 25^{\circ} \mathrm{C}\right.$, TMS $) \delta$ 177.01, 144.22, 142.22, 140.49, 138.80, 135.99, 134.51, 131.17, $130.60,127.11,126.32,122.14,121.83,121.70,120.36,116.81$, 116.64, 42.67, 21.00, and 20.68. MS (ESI) for $\mathrm{C}_{24} \mathrm{H}_{20} \mathrm{~N}_{4} \mathrm{O}$ $[\mathrm{M}+\mathrm{H}]^{+}$, calcd: 381.1669 , found: 381.1660 .

2.3.10. 2-(4-((2-Methyl-9-oxoacridin-10(9H)-yl)methyl)-1H1,2,3-triazol-1-yl)benzoic Acid (2h). Yellow solid; yield: 78\%, $\mathrm{mp}>300^{\circ} \mathrm{C}$. IR (KBr): $3400,3121,3052,1704,1640,1605$, and $1501 \mathrm{~cm}^{-1} .{ }^{1} \mathrm{H}$ NMR $\left(300 \mathrm{MHz}\right.$, DMSO- $\mathrm{d}_{6}, 25^{\circ} \mathrm{C}$, TMS $)$ $\delta 8.92$ (s, $1 \mathrm{H}, \mathrm{CH}$-triazole), 8.39 (d, $J=7.9 \mathrm{~Hz}, 1 \mathrm{H}, \mathrm{Ar}-\mathrm{H})$, 8.15 (s, 1H, Ar-H), 7.96-7.87 (m, 2H, Ar-H), 7.69-7.61 (m, $5 \mathrm{H}, \mathrm{Ar}-\mathrm{H}), 7.31-7.26$ (m, 2H, Ar-H), 5.81 (s, 2H, CH2), and $2.44(\mathrm{~s}, 3 \mathrm{H}, \mathrm{CH} 3) .{ }^{13} \mathrm{C}$ NMR $\left(75 \mathrm{MHz}, \mathrm{DMSO}_{6}, 25^{\circ} \mathrm{C}\right.$, TMS) $\delta 176.01,166.96,142.46,141.71,140.56,138.37,136.61$, $134.89,133.01,129.82,126.74,125.82,121.75,120.80,116.35$, 115.06, 41.93, and 20.37. MS (ESI) for $\mathrm{C}_{24} \mathrm{H}_{18} \mathrm{~N}_{4} \mathrm{O}_{3}[\mathrm{M}+$ $\mathrm{H}]^{+}$, calcd: 411.0883 , found: 411.0884 .

\section{Results and Discussion}

3.1. Synthesis. The new 1,2,3-triazole compounds derived from acridone were synthesized under mild conditions via a two-step reaction. The first step was the $\mathrm{N}$-alkylation of acridone ring. The tautomerism of acridone nucleus contributes to the low basicity of the nitrogen, so the $\mathrm{N}$-alkylation of the acridone nucleus is a relatively difficult reaction. However, the use of a strong base such as potassium carbonate in an anhydrous medium is required for the deprotonation of acridone ring. The preparation of 10-(prop-2-yn-1-yl)acridone derivatives (1) was achieved by $N$-propargylation of acridone under microwave irradiation using solid-liquid phase transfer catalyst. A mixture of acridone (1 equiv) with propargyl bromide ( 1.5 equiv), anhydrous potassium carbonate (1.2 equiv), and tetra- $n$-butylammonium bromide (TBAB) (1 equiv) in DMF was reacted under microwave irradiation during $10 \mathrm{~min}$, after completion of the reaction compound (1) was isolated in good yield (70\%) (Scheme 1).

The second step was the 1,3-dipolar cycloaddition between 10-(prop-2-yn-1-yl)acridone derivatives (1) and aromatic azides. 2-Azidotoluene, 3-azidotoluene, 2azidobenzoic acid, and 4-azidobenzoic acid were prepared from $o$-toluidine, $m$-toluidine, and $p$-anthranilic acid, respectively, by diazotization of amine function followed by nucleophilic substitution reaction with sodium azide $\left(\mathrm{NaN}_{3}\right)$. The new 1,2,3-triazole compounds were prepared using microwave-assisted synthesis (MW) and conventional heating methods, which include the cycloaddition reaction between 10-(prop-2-yn-1-yl)acridone derivatives and a variety of substituted aromatic azides in the presence of copper iodide $(\mathrm{CuI})$ as source of $\mathrm{Cu}(\mathrm{I})$ and triethylamine. First, our investigation focused on exploring the 1,3-dipolar cycloaddition reaction using the conventional heating method, and the reaction was realized in the presence of $\mathrm{CuI}$ (1 equiv) and triethylamine (1.2 equiv) in DMF for $4-8 \mathrm{~h}$ at $80^{\circ} \mathrm{C}$. In these conditions, the compounds $(2 \mathrm{a}-\mathrm{h})$ were obtained in $48-62 \%$ yields.

In the view, to obtain $1,2,3$ triazoles derivatives with excellent yield and shorter reaction times under mild reaction conditions, we have used the microwave-assisted synthesis method. The cycloaddition reaction between 2 azidotoluene and 10-(prop-2-yn-1-yl)acridone 1a was used as a model reaction to study the effect of reaction parameters such as solvents (tert-butanol $(\mathrm{t}-\mathrm{BuOH}), \mathrm{N}, \mathrm{N}$-dimethylformamide (DMF), chloroform $\left(\mathrm{CHCl}_{3}\right)$, and methanol $\left(\mathrm{CH}_{3} \mathrm{OH}\right)$ ), copper salt (CuI (0.1-1 equiv)), microwave exposure time $(2-15 \mathrm{~min})$, and microwave power $(60-200 \mathrm{~W})$ were investigated in order to get optimum conditions. Figure 1 and Table 1 present the effect of various reaction parameters on cycloaddition reaction efficiency.

The effect of time reaction was examined by changing time interval from $2 \mathrm{~min}$ to $15 \mathrm{~min}$ keeping the stoichiometric quantity of 10-(prop-2-yn-1-yl)acridone ( $1 \mathrm{mmol}), 2$ azidotoluene $(2 \mathrm{mmol})$, CuI $(0.5 \mathrm{mmol}), \mathrm{Et}_{3} \mathrm{~N}(0.6 \mathrm{mmol})$ with microwave power $(\max 200 \mathrm{~W})$, and the total reaction volume of $10 \mathrm{~mL}$. The results are displayed in Figure 1(a). The yield of cycloaddition reaction was increased from $12 \%$ to $90 \%$, with increased exposure time from $2 \mathrm{~min}$ to $10 \mathrm{~min}$ in DMF. Whereas, a modest increase in the yield of product (2a) in methanol was observed with $38 \%$; this is probably due to the low solubility of 10-(prop-2-yn-1-yl)acridone in methanol. 
<smiles>O=c1c2ccccc2[nH]c2ccccc12</smiles><smiles>C#CCBr</smiles><smiles>CC#CCn1c2ccc[R1]c2c(=O)c2ccccc21</smiles>

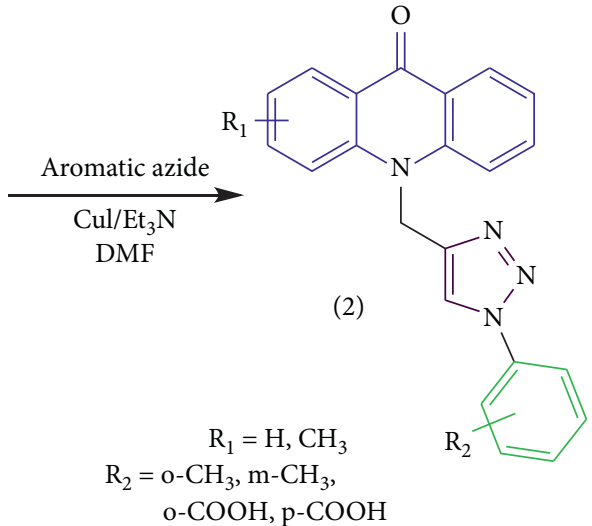

Scheme 1: The synthetic route of 1,2,3-triazole derivatives from acridone.

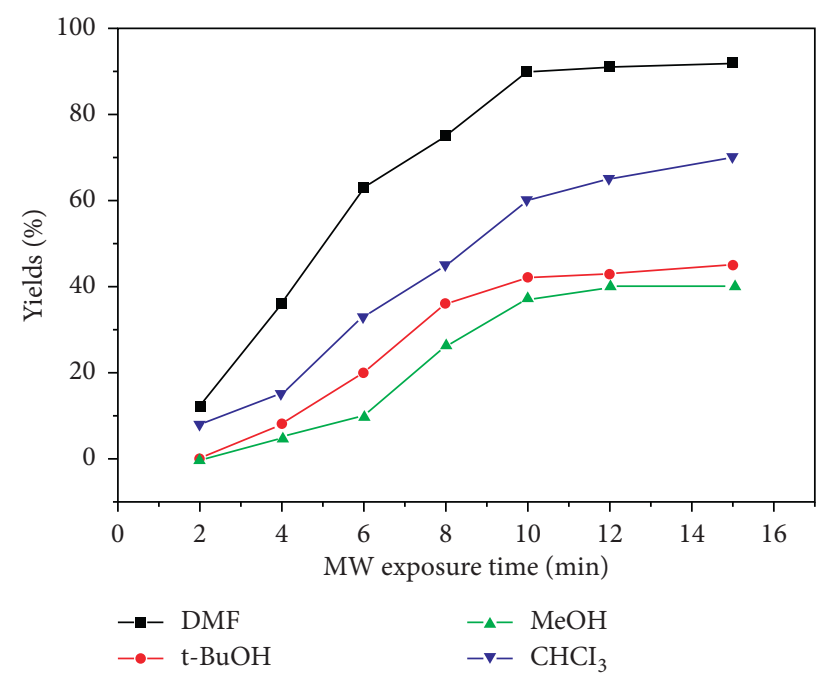

(a)

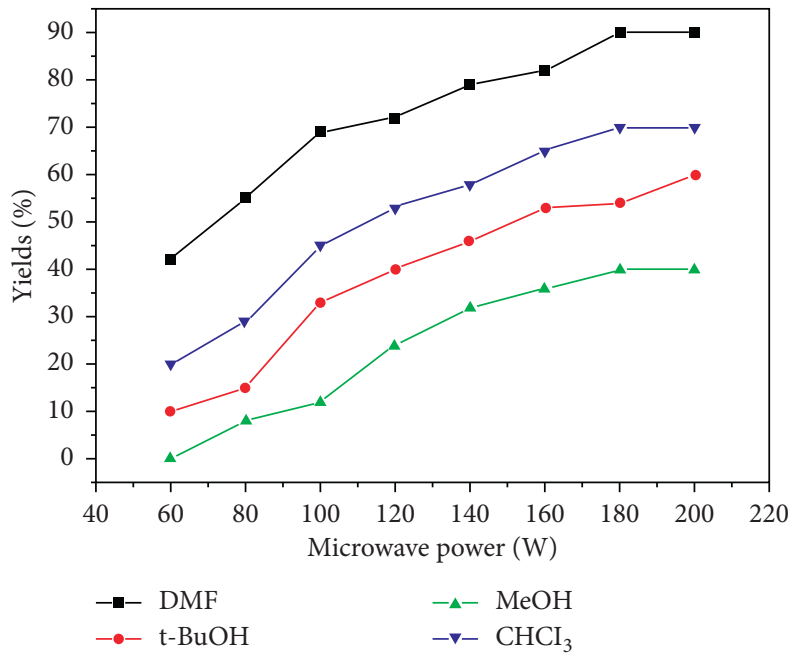

(b)

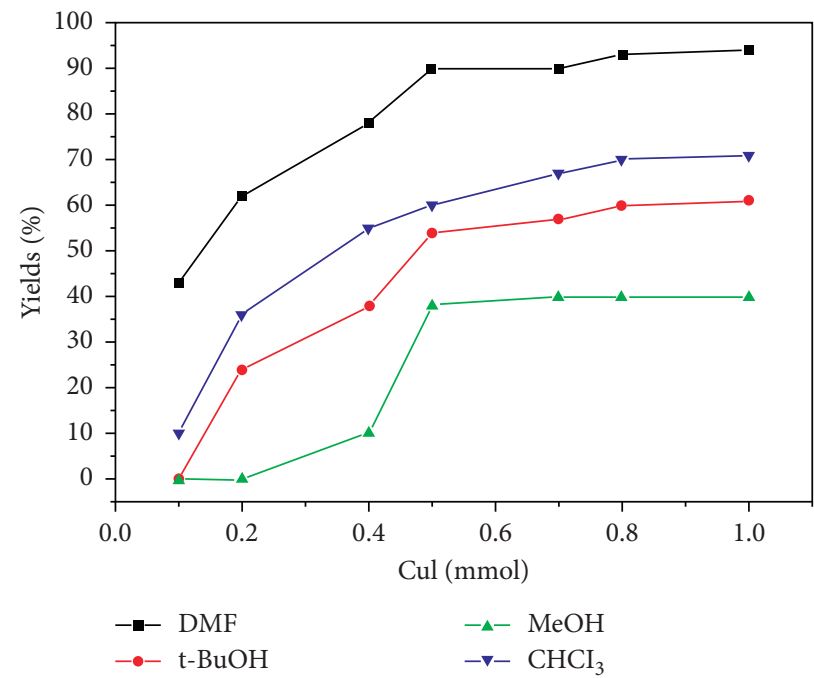

(c)

Figure 1: Optimization of cycloaddition reaction by varying (a) MW exposure time, (b) MW power, and (c) CuI (\%). 
TABle 1: Optimization of reaction condition 2a.

\begin{tabular}{lccccc}
\hline Entry & Copper salt & Base & Solvent & Time & Yields (\%) \\
\hline $1^{\mathrm{a}}$ & $\mathrm{CuI}$ & $\mathrm{Et}_{3} \mathrm{~N}$ & $\mathrm{t}-\mathrm{BuOH}$ & $10 \mathrm{~min}$ & 52 \\
$2^{\mathrm{a}}$ & $\mathrm{CuI}$ & $\mathrm{Et}_{3} \mathrm{~N}$ & $\mathrm{DMF}$ & $10 \mathrm{~min}$ & 90 \\
$3^{\mathrm{a}}$ & $\mathrm{CuI}$ & $\mathrm{Et}_{3} \mathrm{~N}$ & $\mathrm{CHCl}_{3}$ & $10 \mathrm{~min}$ & 62 \\
$4^{\mathrm{a}}$ & $\mathrm{CuI}$ & $\mathrm{Et}_{3} \mathrm{~N}$ & $\mathrm{MeOH}$ & $10 \mathrm{~min}$ & 38 \\
$5^{\mathrm{a}}$ & $\mathrm{CuI}$ & $\mathrm{Et}_{3} \mathrm{~N}$ & $\mathrm{DMF}$ & $15 \mathrm{~min}$ & 92 \\
$6^{\mathrm{b}}$ & $\mathrm{CuI}$ & $\mathrm{Et}_{3} \mathrm{~N}$ & $\mathrm{DMF}$ & $10 \mathrm{~min}$ & 94 \\
$7^{\mathrm{c}}$ & $\mathrm{CuI}$ & $\mathrm{Et}_{3} \mathrm{~N}$ & $\mathrm{DMF}$ & $4 \mathrm{~h}$ & 62 \\
\hline
\end{tabular}

${ }^{a}$ Reaction conditions: 10-(prop-2-yn-1-yl)acridone (1 mmol), 2-azidotoluene ( $2 \mathrm{mmol})$, copper iodide $(0.5 \mathrm{mmol})$, Et $3 \mathrm{~N}(0.6 \mathrm{mmol})$, and MW $200 \mathrm{~W}$

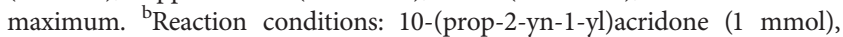
2-azidotoluene ( $2 \mathrm{mmol})$, copper iodide ( $1 \mathrm{mmol}$ ), Et3N (1.2 mmol), and MW $200 \mathrm{~W}$ maximum. ${ }^{\mathrm{c}}$ Reaction conditions: 10-(prop-2-yn-1-yl)acridone (1 $\mathrm{mmol}), 2$-azidotoluene $(2 \mathrm{mmol})$, copper iodide $(1 \mathrm{mmol})$, and Et3N $(1.2$ $\mathrm{mmol}$ ) at $80^{\circ} \mathrm{C}$ (conventional heating).

The effect of microwave power on cycloaddition reaction was studied by altering microwave power from $60 \mathrm{~W}$ to $200 \mathrm{~W}$, at fixed stoichiometric quantity of 10-(prop-2-yn-1-yl) acridone ( $1 \mathrm{mmol}), 2$-azidotoluene $(2 \mathrm{mmol}), \mathrm{CuI}(0.5 \mathrm{mmol})$, $\mathrm{Et}_{3} \mathrm{~N}(0.6 \mathrm{mmol})$ with exposure time $(10 \mathrm{~min})$, and the total reaction volume of $10 \mathrm{~mL}$. The results are shown in Figure 1(b). The yield of cycloaddition reaction increased almost linearly from $42 \%$ to $90 \%$, with augmentation of microwave power from $60 \mathrm{~W}$ to $180 \mathrm{~W}$ in DMF. Also, an interesting increase in the yield of product (2a) in chloroform with $70 \%$ in $10 \mathrm{~min}$ was observed. The reason of this performance is attributed to the thermal and nonthermal microwave effects. The thermal effects in these reactions involve selective heating in solution and accumulation of heat in polar species. The nonthermal effects are due to a specific contribution of electrostatic field resulting from dipoles-dipoles interactions between polar molecules and the electric field, which lead to the polarizability and the stabilization of transition states under microwave irradiation.

The percentage of copper salt and triethylamine was examined by varying the initiator concentration from 0.1 to 1 equivalent for $\mathrm{CuI}$ and from 0.12 to 1.2 equivalent for $\mathrm{Et}_{3} \mathrm{~N}$ at fixed stoichiometric quantity of 10-(prop-2-yn-1-yl) acridone $(1 \mathrm{mmol}), 2$-azidotoluene $(2 \mathrm{mmol})$ with exposure time $(10 \mathrm{~min})$, microwave power $(\max 200 \mathrm{~W})$, and the total reaction volume of $10 \mathrm{~mL}$; the results are shown in Figure 1(c). It was found that the yield of the cycloaddition reaction was increased from $43 \%$ to $90 \%$ with increased percentage of copper salt from 0.1 to 0.5 equivalent in DMF. While a weak increase in the yield of compound (2a) in $\mathrm{t}-\mathrm{BuOH}$ was observed, the yield of cycloaddition reaction was improved from $0 \%$ to $40 \%$ with increased percentage of copper salt from 0.1 to 0.5 equivalent. The direct use of copper salt in its oxidation state (I), brought in the form of copper iodide $(\mathrm{CuI})$ in an inert medium $\left(\mathrm{N}_{2}\right)$, allowed to obtain the new 1,4-disubstituted 1,2,3-triazoles with good yields. The use of triethylamine $\left(\mathrm{Et}_{3} \mathrm{~N}\right)$ was necessary to stabilize $\mathrm{Cu}(\mathrm{I})$ against oxidation; moreover, triethylamine facilitates deprotonation of CuI-acetylide.

As observed from Figure 1, the optimum reaction conditions for synthesis of 10-((1-(o-tolyl)-1H-1,2,3-triazol-4-yl) methyl)acridone (2a) were obtained in DMF as solvent and with stoichiometric quantities of 10-(prop-2-yn-1-yl)acridone (1 mmol), 2-azidotoluene $(2 \mathrm{mmol})$, CuI $(0.5 \mathrm{mmol})$, and $\mathrm{Et}_{3} \mathrm{~N}(0.6 \mathrm{mmol})$ at $200 \mathrm{~W}$ with exposure time of $10 \mathrm{~min}$. After optimizing the conditions of the cycloaddition reaction, we applied these conditions to the 10-(prop-2-yn-1-yl)acridone derivatives used as dipolarophiles with the different aromatic azides used as dipoles, in the presence of the catalytic system $\mathrm{CuI} / \mathrm{Et}_{3} \mathrm{~N}$ in DMF. After $10 \mathrm{~min}$, the conversion of the starting product is generally complete, and the purification of the product was carried out by successive washings with dichloromethane and water, followed by a recrystallization in $\mathrm{DMF} /$ methanol mixture.

Comparative study results obtained by microwaveassisted synthesis versus the conventional heating method showed that the conventional heating required more reaction time ( $4-8 \mathrm{~h})$; however, all the reactions were completed within 10 min under the microwave irradiation method which caused significant reduction in the reaction times, and the yields have been improved from 48-62\% (conventional heating) to $75-90 \%$ (microwave-assisted reaction) (Table 2). This procedure of click chemistry allowed us to obtain only the 1,4 disubstituted regioisomer.

\subsection{Characterization of Synthesized Compound (2a-h).}

The structures of the 1,4-disubstituted triazoles $(2 \mathrm{a}-\mathrm{h})$ synthesized using the synthetic protocol described above were fully characterized by NMR, IR and HRMS analyses.

3.2.1. FTIR Spectroscopy. To confirm the structure of synthesized compounds, the reactions were monitored by FTIR; the IR spectrum of compounds $2 \mathrm{a}-\mathrm{h}$ shows the disappearance of the vibration bonds of the alkyne group in the region of $2110 \mathrm{~cm}^{-1}$ and $3210 \mathrm{~cm}^{-1}$ confirmed the formation of the synthesized compounds. Moreover, the FTIR spectra displayed characteristic absorption bands in the region of $1640-1630 \mathrm{~cm}^{-1}$ assigned to the bond $(\mathrm{C}=\mathrm{O})$ of the acridone ring, and characteristic bands of triazole ring were detected in the range of $1500-1300 \mathrm{~cm}^{-1}$ corresponding to $\mathrm{N}=\mathrm{N}$ and $\mathrm{C}=\mathrm{C}$ bonds. In addition, compounds $2 \mathrm{~b}, 2 \mathrm{~d}, 2 \mathrm{f}$, and $2 \mathrm{~h}$ showed bands around $3400 \mathrm{~cm}^{-1}, 3010-2920 \mathrm{~cm}^{-1}$, and $1700 \mathrm{~cm}^{-1}$, demonstrating characteristic stretching vibration of $\mathrm{O}-\mathrm{H}$, aromatic and aliphatic $\mathrm{C}-\mathrm{H}$, and carbonyl $(\mathrm{C}=\mathrm{O})$ of the carboxylic acid group, respectively.

3.2.2. NMR Analyses. In order to confirm the synthesized compounds $2 \mathrm{a}-\mathrm{h}$, NMR spectroscopic analysis was investigated. The ${ }^{1} \mathrm{H}$ NMR spectra showed aromatic protons between $8.95 \mathrm{ppm}$ and $7.25 \mathrm{ppm}$. We also noticed the presence of signals between $5.92 \mathrm{ppm}$ and $5.85 \mathrm{ppm}$ attributable to the protons of the methylene group $\left(\mathrm{N}-\mathrm{CH}_{2}\right)$, in addition to a singlet at $8.95-8.59 \mathrm{ppm}$ attributable to the proton of the triazole nucleus. In the ${ }^{1} \mathrm{H}$ NMR spectrum of compound $2 \mathrm{e}$, the characteristic signal of triazole was observed at $8.59 \mathrm{ppm}$. The signal at $5.89 \mathrm{ppm}$ attributed to the hydrogens of the methylene group $\left(\mathrm{N}_{-} \mathrm{CH}_{2}\right)$, and the signals of the methyl group were observed at $2.46 \mathrm{ppm}$ and $2.10 \mathrm{ppm}$ (Figure 2). 
TABLE 2: Synthesized compounds $(2 \mathrm{a}-\mathrm{h})$.

\begin{tabular}{lcccc}
\hline Compounds & $\mathrm{R} 1$ & $\mathrm{R} 2$ & Yield (\%) microwave method & Yield (\%) conventional method \\
\hline $2 \mathrm{a}$ & $\mathrm{H}$ & $\mathrm{o}-\mathrm{CH}_{3}$ & 90 & 62 \\
$2 \mathrm{~b}$ & - & $\mathrm{p}-\mathrm{COOH}$ & 79 & 50 \\
$2 \mathrm{c}$ & - & $\mathrm{m}-\mathrm{CH}_{3}$ & 85 & 58 \\
$2 \mathrm{~d}$ & & $\mathrm{o}-\mathrm{COOH}$ & 75 & 48 \\
$2 \mathrm{e}$ & $\mathrm{o}-\mathrm{CH}_{3}$ & 89 & 60 \\
$2 \mathrm{f}$ & $\mathrm{CH}_{3}-$ & $\mathrm{p}-\mathrm{COOH}$ & 82 & 51 \\
$2 \mathrm{~g}$ & - & $\mathrm{m}-\mathrm{CH}_{3}$ & 81 & 60 \\
$2 \mathrm{~h}$ & & $\mathrm{o}-\mathrm{COOH}$ & 78 & 48 \\
\hline
\end{tabular}
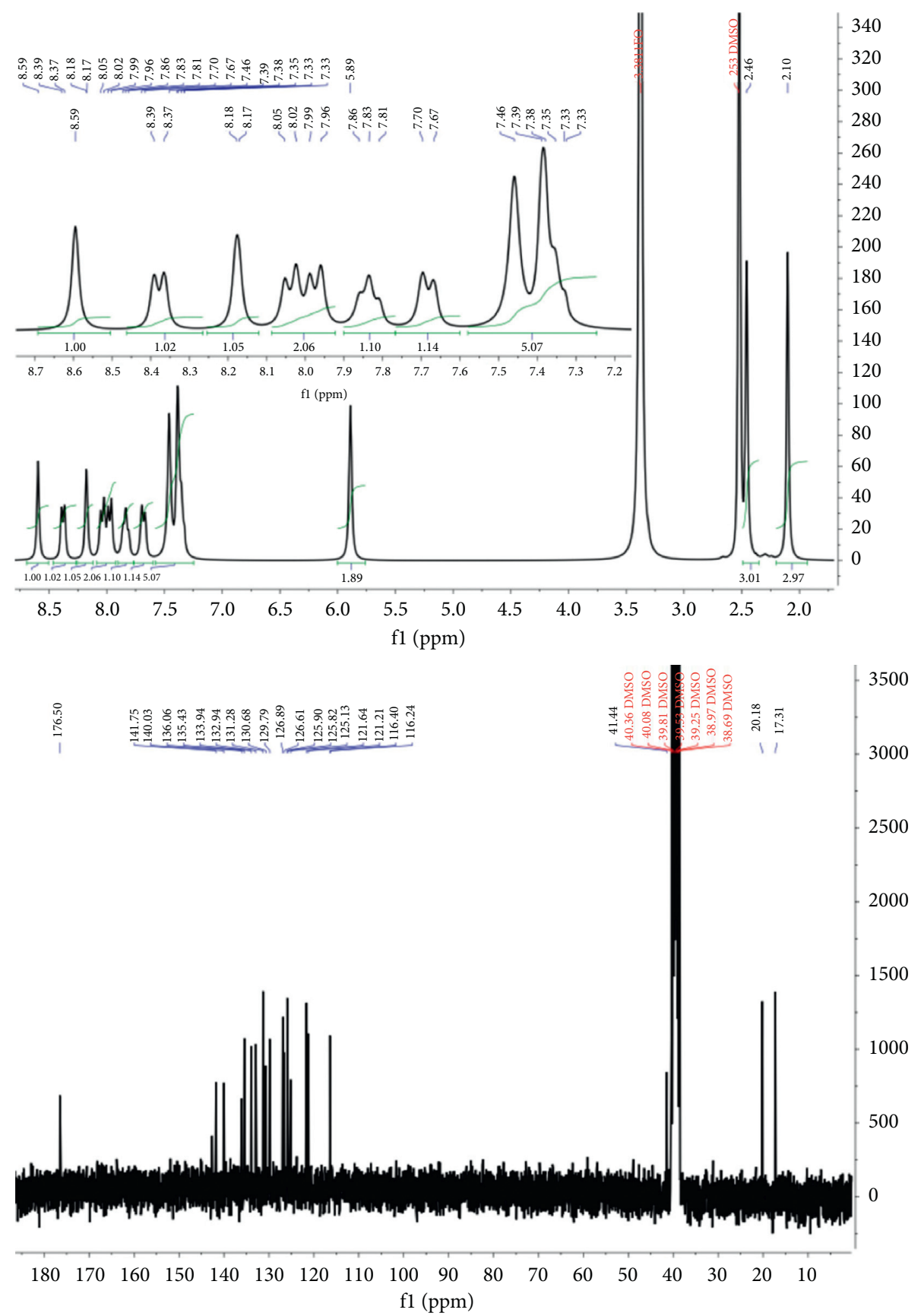

Figure 2: ${ }^{1} \mathrm{H}$ NMR and ${ }^{13} \mathrm{C}$ NMR spectra of compound 2e in DMSO- $\mathrm{d}_{6}$. 


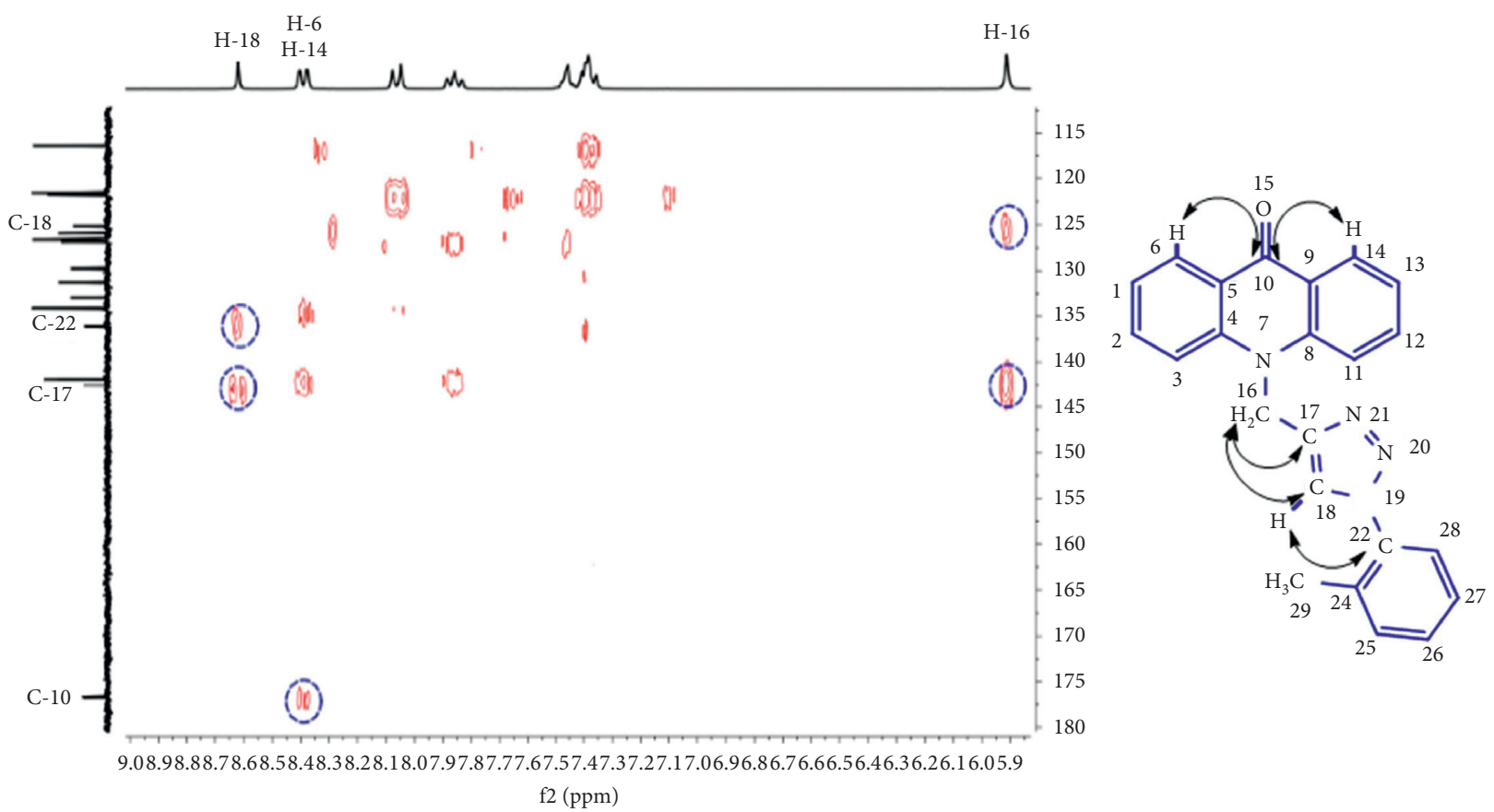

Figure 3: The ${ }^{1} \mathrm{H}^{-}{ }^{13} \mathrm{C}$ HMBC spectrum of compound 2a.

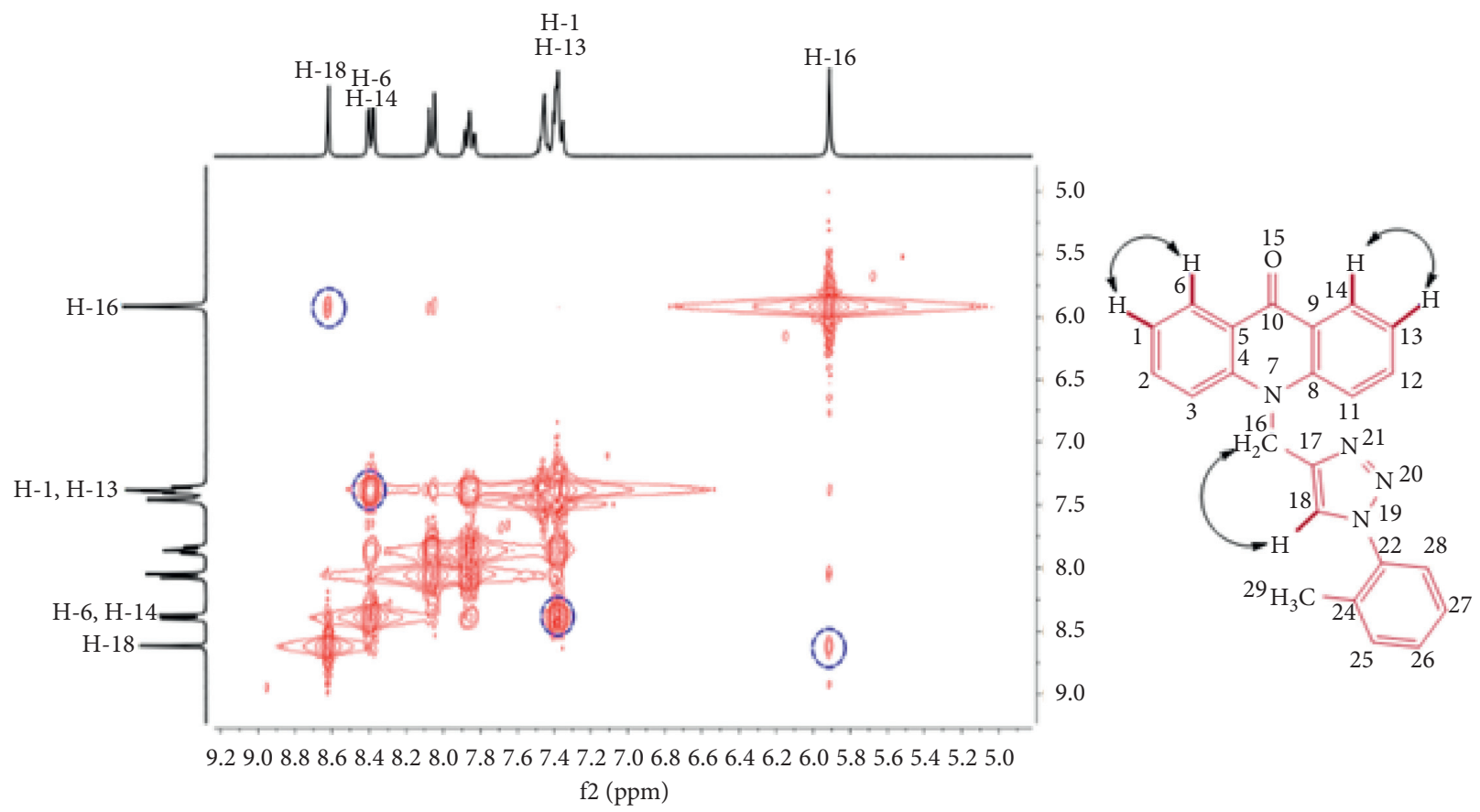

Figure 4: The ${ }^{1} \mathrm{H}-{ }^{1} \mathrm{H}$ COSY spectrum of compound 2a.

These structures were further supported by ${ }^{13} \mathrm{C}$ and DEPT NMR spectra, which showed all the expected carbon signals corresponding to acridone-triazole derivatives, especially the aromatic carbons of triazole ring resonating between $125 \mathrm{ppm}$ and $143 \mathrm{ppm}$ and signals of methylene carbons resonated between $50 \mathrm{ppm}$ and $41 \mathrm{ppm}$. We also noticed the presence of signal between $177 \mathrm{ppm}$ and $176 \mathrm{ppm}$ attributed to the carbonyl $(\mathrm{C}=\mathrm{O})$ of the acridone ring.
The regioselectivity of the cycloaddition reaction under microwave irradiation was confirmed by using $2 \mathrm{D}$ NMR. The HMBC experiment is an important tool to identify the structure of synthetic compounds. Therefore, the strategy for identifying above structure is conveniently realized on the basis of long-range connectivities via ${ }^{1} \mathrm{H}_{-}{ }^{13} \mathrm{C} \mathrm{HMBC}$ depending on the correlation between the triazole protons with the adjacent carbons. For instance, in the ${ }^{1} \mathrm{H}-{ }^{13} \mathrm{C}$ $\mathrm{HMBC}$ spectrum of the compound $2 \mathrm{a}$, the protons of the 


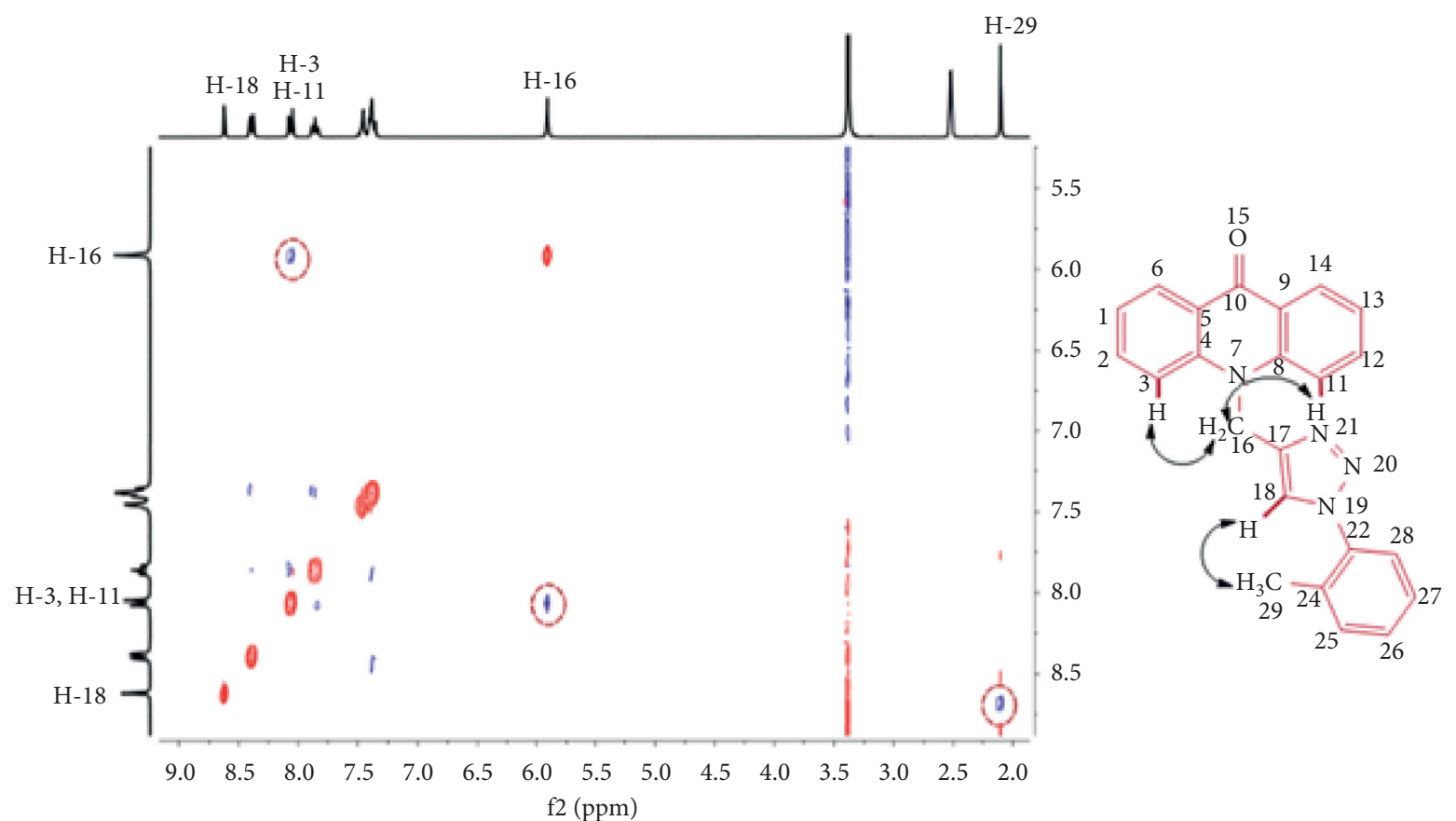

Figure 5: The ${ }^{1} \mathrm{H}-{ }^{1} \mathrm{H}$ NOESY spectrum of compound $2 \mathrm{a}$.

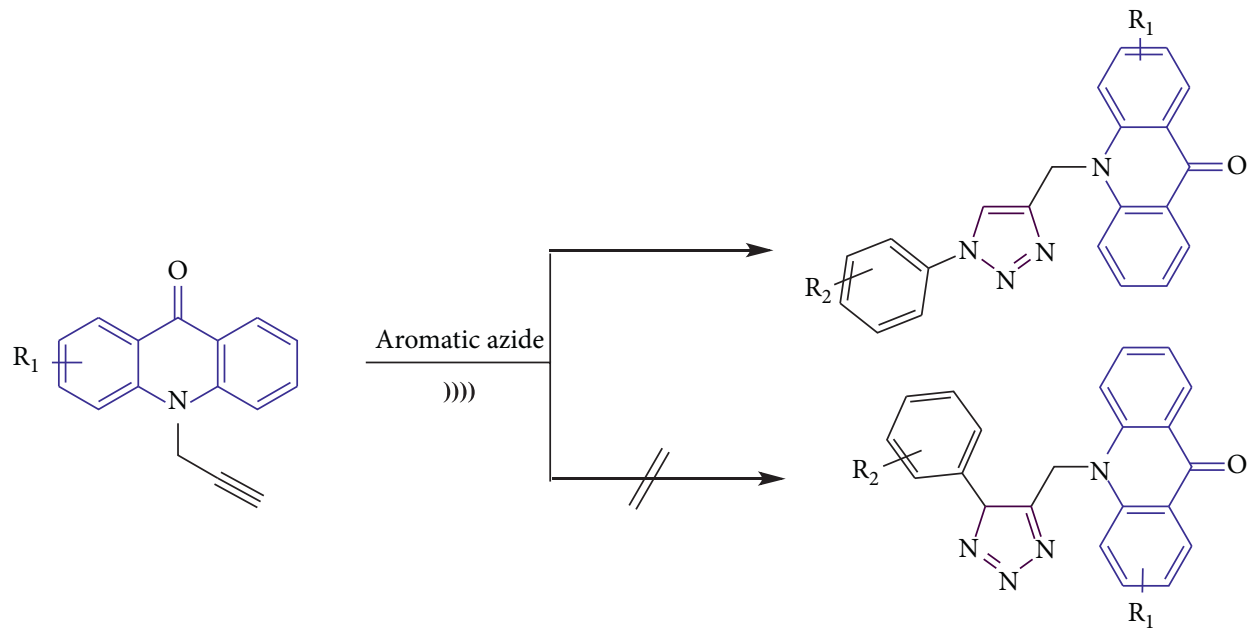

Figure 6: Synthesis of 1,4-disubstituted triazole.

methylene group $\left(\mathrm{NCH}_{2}\right)$ at $5.91 \mathrm{ppm}$ correlates to the triazole carbons at $142.5 \mathrm{ppm}\left({ }^{2} \mathrm{~J}_{\mathrm{H}-\mathrm{C}}\right)(\mathrm{C}-17)$ and $125.1 \mathrm{ppm}$ $\left({ }^{3} \mathrm{~J}_{\mathrm{H}-\mathrm{C}}\right)(\mathrm{C}-18)$; in addition, the proton of triazole ring $(\mathrm{H}-18)$ at $8.62 \mathrm{ppm}$ correlates with quaternary carbon of the phenyl group (C-22) at $136 \mathrm{ppm}\left({ }^{3} \mathrm{~J}_{\mathrm{H}-\mathrm{C}}\right)$ and the carbon of triazole ring $(\mathrm{C}-17)$ at $142.5 \mathrm{ppm}\left({ }^{2} \mathrm{~J}_{\mathrm{H}-\mathrm{C}}\right)$. Also, we notice that the carbonyl functional group at $176.6 \mathrm{ppm}$ correlates to the protons of acridone ring at $8.40 \mathrm{ppm}\left({ }^{3} \mathrm{~J}_{\mathrm{H}-\mathrm{C}}\right)$ (Figure 3).

Another evidence came from the study of ${ }^{1} \mathrm{H}^{-}{ }^{1} \mathrm{H}$ COSY and ${ }^{1} \mathrm{H}-{ }^{1} \mathrm{H}$ NOESY spectra of the compound 2a. Accordingly, the ${ }^{1} \mathrm{H}-{ }^{1} \mathrm{H}$ COSY spectrum shows correlations between the proton of triazole ring $(\mathrm{H}-18)$ at $8.62 \mathrm{ppm}$ and the protons of the methylene group $\left(\mathrm{NCH}_{2}\right)(\mathrm{H}-16)$ at $5.91 \mathrm{ppm}$, in addition to correlations between the protons of acridone ring $(\mathrm{H}-6, \mathrm{H}-14)$ at $8.40 \mathrm{ppm}$ and the protons $(\mathrm{H}-1$, $\mathrm{H}-13$ ) at $7.38 \mathrm{ppm}$ (Figure 4). The ${ }^{1} \mathrm{H}-{ }^{1} \mathrm{H}$ NOESY spectrum shows correlations between the protons of the methylene group $\left(\mathrm{NCH}_{2}\right)(\mathrm{H}-16)$ at $5.91 \mathrm{ppm}$ and the protons of acridone ring $(\mathrm{H}-3, \mathrm{H}-11)$ at $8.05 \mathrm{ppm}$. Also, we observe that the signal of the proton of triazole ring $(\mathrm{H}-18)$ at $8.62 \mathrm{ppm}$ correlate with methyl of the phenyl group $\left(\mathrm{CH}_{3}\right)$ at $2.11 \mathrm{ppm}$ (Figure 5). 
Therefore, these results confirm the formation of 1,4-disubstituted regioisomer. Thus, the regioselectivity of the 1,3-dipolar cycloaddition reaction between 10-(prop-2-yn-1-yl) acridone derivatives (2) and aromatic azides under microwave irradiation was attained (Figure 6).

\section{Conclusion}

Facile synthetic routes are designed to synthesis new 1,2,3triazole compounds derived from acridone via regiospecific 1,3-dipolar cycloaddition reaction catalyzed by $\mathrm{Cu}(\mathrm{I})$. The microwave irradiation method offered high yields of 1,2,3triazoles in a short reaction time compared with the conventional method. The structure of the novel compounds was determined by NMR, FTIR spectroscopy, and mass spectrometry. The regioselectivity of the cycloaddition reaction has been confirmed unambiguously by the multinuclear NMR $\left({ }^{1} \mathrm{H}^{13}{ }^{13} \mathrm{CHBC},{ }^{1} \mathrm{H}^{-}{ }^{1} \mathrm{H}\right.$ COSY, and ${ }^{1} \mathrm{H}-{ }^{1} \mathrm{H}$ NOESY).

\section{Data Availability}

The data used to support the findings of this study are included in the supplementary file.

\section{Conflicts of Interest}

The authors declare that they have no conflicts of interest.

\section{Acknowledgments}

The authors gratefully acknowledge the research team, Molecular Chemistry and Bioactive Molecules, Faculty of Science, Moulay Ismail University, for providing necessary facilities to carry out the research work. The authors also acknowledge the National School of Agriculture Meknes, for providing the facility for access to the microwave (electronic supplementary materials).

\section{Supplementary Materials}

The supplementary data contain IR, ${ }^{1} \mathrm{H},{ }^{13} \mathrm{C}$ NMR, and mass spectroscopy charts of the new synthesized compounds. (Supplementary Materials)

\section{References}

[1] Z. Rezaei, S. Khabnadideh, K. Zomorodian et al., "Design, synthesis and antifungal activity of some new imidazole and triazole derivatives," Archiv der Pharmazie, vol. 344, no. 10, pp. 658-665, 2011.

[2] M. Aarjane, S. Slassi, B. Tazi, M. Maouloua, and A. Amine, "Novel series of acridone-1,2,3-triazole derivatives: microwave-assisted synthesis, DFT study and antibacterial activities," Journal of Chemical Sciences, vol. 131, no. 8, pp. 1-11, 2019.

[3] G. Zoidis, E. Kritsi, P. Lecinska et al., "The triazole ring as a privileged scaffold for putative antifungals: synthesis and evaluation of a series of new analogues," ChemMedChem, vol. 16, no. 1, pp. 134-144, 2021.
[4] G. Turan-Zitouni, Z. A. Kaplancikli, A. Özdemir, P. Chevallet, H. B. Kandilci, and B. Gümüsel, "Studies on 1,2,4-triazole derivatives as potential anti-inflammatory agents," Archiv der Pharmazie, vol. 340, no. 11, pp. 586-590, 2007.

[5] A. N. Boshra, H. H. M. Abdu-Allah, A. F. Mohammed, and A. M. Hayallah, "Click chemistry synthesis, biological evaluation and docking study of some novel 2'-hydroxychalconetriazole hybrids as potent anti-inflammatory agents," Bioorganic Chemistry, vol. 95, Article ID 103505, 2020.

[6] M. B. Tehrani, P. Emani, Z. Rezaei et al., "Phthalimide-1, 2,3-triazole hybrid compounds as tyrosinase inhibitors; synthesis, biological evaluation and molecular docking analysis," Journal of Molecular Structure, vol. 1176, pp. 86-93, 2019.

[7] N. Pokhodylo, O. Shyyka, and V. Matiychuk, "Synthesis and anticancer activity evaluation of new 1,2,3-triazole-4-carboxamide derivatives," Medicinal Chemistry Research, vol. 23, no. 5, pp. 2426-2438, 2014.

[8] D. Kanabar, P. Farrales, A. Kabir et al., "Optimizing the aryltriazole of cjoc42 for enhanced gankyrin binding and anticancer activity," Bioorganic \& Medicinal Chemistry Letters, vol. 30, no. 17, Article ID 127372, 2020.

[9] S. Dey, T. Sarkar, A. Majumdar, T. Pathak, and K. Ghosh, "1,4-Disubstituted 1,2,3-triazole- and 1,5-disubstituted 1,2,3triazole-based bis-sulfonamides in selective fluorescence sensing of ATP," ChemistrySelect, vol. 2, no. 6, pp. 2034-2038, 2017.

[10] D. Sikora and T. Gajda, "A new approach to the synthesis of functionalized 1-alkenyl-1H-1,2,3-triazoles," Tetrahedron, vol. 54, no. 10, pp. 2243-2250, 1998.

[11] G. Surendra Reddy, K. Anebouselvy, and D. B. Ramachary, "[3+2]-Cycloaddition for the fully decorated vinyl-1,2,3-triazoles: design, synthesis and applications," Chemistry-An Asian Journal, vol. 15, pp. 2960-2983, 2020.

[12] R. Huisgen, R. Grashey, and J. Sauer, "Cycloaddition reactions of alkenes," in Alkenes, vol. 1, pp. 739-953, John Wiley and Sons Ltd., Chichester, UK, 2010.

[13] A. Tripathi, C. V. Rode, J. Llop, S. P. Chavan, and S. M. Joshi, "An enolate-mediated regioselective synthesis of 1,2,3-triazoles via azide-aldehydes or ketones [3+2]-cycloaddition reactions in aqueous phase," Tetrahedron Letters, vol. 61, no. 13, Article ID 151662, 2020.

[14] V. Turukarabettu, B. Kalluraya, K. Hemanth, and B. C. Revanasiddappa, " $\mathrm{Cu}(\mathrm{I})$ catalyzed 1,3-dipolar click synthesis of S-heterocyclic 1,2,3-triazole derivatives, their antibacterial activity," Russian Journal of General Chemistry, vol. 90, no. 1, pp. 142-147, 2020.

[15] Z. Li, Y. Huang, D. Fan, H. Li, S. Liu, and L. Wang, "Synthesis and properties of novel organogelators functionalized with 5iodo-1,2,3-triazole and azobenzene groups," Frontiers of Chemical Science and Engineering, vol. 10, no. 4, pp. 552-561, 2016.

[16] D. Cao, R. Wu, S. Dong et al., "Triazole resistance in Aspergillus fumigatus in crop plant soil after tebuconazole applications," Environmental Pollution, vol. 266, Article ID 115124, 2020.

[17] N. Takahashi, Subehan, S. Kadota, and Y. Tezuka, "Mechanism-based CYP2D6 inactivation by acridone alkaloids of Indonesian medicinal plant Lunasia amara," Fitoterapia, vol. 83, no. 4, pp. 774-779, 2012.

[18] K. Kamanna, R. Aneja, C. Duffy et al., "Non-natural peptide triazole antagonists of HIV-1 envelope gp120," ChemMedChem, vol. 8, no. 2, pp. 322-328, 2013. 
[19] C. S. Sepúlveda, C. C. García, M. L. Fascio et al., "Inhibition of Junin virus RNA synthesis by an antiviral acridone derivative," Antiviral Research, vol. 93, no. 1, pp. 16-22, 2012.

[20] M. Aarjane, S. Slassi, B. Tazi, and A. Amine, "Synthesis and biological evaluation of novel isoxazole derivatives from acridone," Archiv der Pharmazie, vol. 354, Article ID 2000261, 2020.

[21] P. Singh, J. Kaur, B. Yadav, and S. S. Komath, "Design, synthesis and evaluations of acridone derivatives using Candida albicans-search for MDR modulators led to the identification of an anti-candidiasis agent," Bioorganic \& Medicinal Chemistry, vol. 17, no. 11, pp. 3973-3979, 2009.

[22] M. Aarjane, S. Slassi, A. Ghaleb, B. Tazi, and A. Amine, "Synthesis, biological evaluation, molecular docking and in silico ADMET screening studies of novel isoxazoline derivatives from acridone," Arabian Journal of Chemistry, vol. 14, no. 4, Article ID 103057, 2021.

[23] C. Gao, W. Zhang, S. He, S. Li, F. Liu, and Y. Jiang, "Synthesis and antiproliferative activity of 2,7-diamino 10-(3,5-dimethoxy) benzyl-9 $(10 \mathrm{H})$-acridone derivatives as potent telomeric G-quadruplex DNA ligands," Bioorganic Chemistry, vol. 60, pp. 30-36, 2015.

[24] S. Dallavalle, V. Dobričić, L. Lazzarato et al., "Improvement of conventional anti-cancer drugs as new tools against multidrug resistant tumors," Drug Resistance Updates, vol. 50, Article ID 100682, 2020

[25] Y.-L. Fan, X.-W. Cheng, J.-B. Wu et al., "Antiplasmodial and antimalarial activities of quinolone derivatives: an overview," European Journal of Medicinal Chemistry, vol. 146, pp. 1-14, 2018.

[26] A. Kumar, K. Srivastava, S. Raja Kumar, S. K. Puri, and P. M. S. Chauhan, "Synthesis of 9-anilinoacridine triazines as new class of hybrid antimalarial agents," Bioorganic \& $\mathrm{Me}$ dicinal Chemistry Letters, vol. 19, no. 24, pp. 6996-6999, 2009.

[27] W. A. Denny and B. C. Baguley, "Acridine-based anticancer drugs," in Molecular Aspects of Anticancer Drug-DNA Interactions, pp. 270-311, Macmillan Education UK, London, UK, 1994.

[28] O. O. Fadeyi, S. T. Adamson, E. L. Myles, and C. O. Okoro, "Novel fluorinated acridone derivatives. Part 1: synthesis and evaluation as potential anticancer agents," Bioorganic \& Medicinal Chemistry Letters, vol. 18, no. 14, pp. 4172-4176, 2008.

[29] M. Aarjane, S. Slassi, and A. Amine, "Novel highly selective and sensitive fluorescent sensor for copper detection based on N-acylhydrazone acridone derivative," Journal of Molecular Structure, vol. 1199, Article ID 126990, 2020.

[30] C. Yuwen, B. Liu, P. Liu, S. Guo, and L. Zhang, "Microwave field: temperature-dependent dielectric properties and heating characteristics during the synthesis of alpha-tellurium dioxide," Materials Chemistry and Physics, vol. 255, Article ID 123637, 2020.

[31] R. Li, J. Liu, L. Xu, and J. Zhou, "Microwave idrothermal synthesis of magnesium-aluminium spinel," Ceramics International, vol. 46, no. 18, p. 29207, 2020.

[32] M. Aarjane, S. Slassi, A. Ghaleb, and A. Amine, "Synthesis, spectroscopic characterization (FT-IR, NMR) and DFT computational studies of new isoxazoline derived from acridone," Journal of Molecular Structure, vol. 1231, Article ID 129921, 2021.

[33] S. Y. Alraqa, K. Alharbi, A. Aljuhani, N. Rezki, M. R. Aouad, and I. Ali, "Design, click conventional and microwave syntheses, DNA binding, docking and anticancer studies of benzotriazole-1,2,3-triazole molecular hybrids with different pharmacophores," Journal of Molecular Structure, vol. 1225, Article ID 129192, 2021.

[34] M. Aarjane, S. Slassi, B. Tazi, M. Maouloua, and A. Amine, "Synthesis, antibacterial evaluation and molecular docking studies of novel series of acridone-1,2,3-triazole derivatives," Structural Chemistry, vol. 31, no. 4, p. 1523, 2020.

[35] J.-N. Chen, X.-K. Wu, C.-H. Lu, and X. Li, "Structure-activity relationship of novel acridone derivatives as antiproliferative agents," Bioorganic \& Medicinal Chemistry, vol. 29, Article ID 115868, 2021.

[36] C. Gao, S. Li, X. Lang et al., "Synthesis and evaluation of 10(3,5-dimethoxy) benzyl-9 (10H)-acridone derivatives as selective telomeric G-quadruplex DNA ligands," Tetrahedron, vol. 68 , no. 38 , pp. 7920-7925, 2012. 